\title{
EPICURUS AND AESTHETIC DISINTERESTEDNESS
}

Aiste Celkyte ${ }^{1}$

ABSTRACT: Aesthetic disinterestedness is one of the central concepts in aesthetics, and Jerome Stolnitz, the most prominent theorist of disinterestedness in the $20^{\text {th }}$ century, has claimed that (i) ancient thinkers engagement with this notion was cursory and undeveloped, and consequently, (ii) the emergence of disinterestedness in the $18^{\text {th }}$ century marks the birth of aesthetics as a discipline. In this paper, I use the extant works of Epicurus to show that the ancient philosopher not only had similar concepts, but also motivated them in careful and complex ways. I argue that, in the Epicurean theoretical framework, arts belong to the category of 'merely natural' desires, and this classification, combined with what we know of Epicurus' rejection of art criticism, shows he had carefully worked out reasons supporting the idea that art ought to be approached terminally, rather than instrumentally. Finally, I compare the notion of aesthetic disinterestedness with Epicurus' views on arts and argue that in many ways the latter are not inferior to the former, and therefore ought to belong to the history of aesthetics.

KEYWORDS: Epicurus; aesthetics; desires; arts.

\section{Introduction}

Aesthetic disinterestedness - the attention to and the appreciation of aesthetic properties purely for the sake of themselves and independently of any external considerations - is one of the central concepts in the discipline aesthetics. Although the notion of aesthetic disinterestedness plays a role in the works of a number of eminent philosophers, such as Kant and Schopenhauer, one of the best-known theorists of aesthetic disinterestedness is Jerome Stolnitz who, in his article entitled 'On The Origins of Aesthetic Disinterestedness', argues that this concept was first properly conceptualised in the works of British philosophers of the $18^{\text {th }}$ century. This theoretical development, moreover, was foundational for the discipline of aesthetics. He also claims that the concept 'either does not occur at all in the thought of antiquity...or if it does...the allusion is cursory and undeveloped.'2 In this paper, I argue not only that there is a similar concept in the Epicurean corpus, but also that the Epicurean account of the proper attitude to the arts provides one example of ancient philosophers' treatment of aesthetic issues that is far from cursory or inchoate.

\footnotetext{
${ }^{1}$ Underwood International College, Yonsei University. Email: aiste.celkyte@gmail.com

${ }^{2}$ Stolnitz 1961:131, cf.138.
} 
My argument is not intended to show that the modern notion and Epicurus' ideas are equivalent or interchangeable. The latter is an integral part of the Epicurean philosophical framework while the former is emblematic of aesthetical discourses that develop in $18^{\text {th }}$ century in Europe. They originated in different contexts and carry very specific - and distinct - theoretical implications. My goal is simply to find an ancient argument for the conclusion that aesthetic values ought to be appreciated independently of other values while at the same time noting the significance of this argument in the context in which it was made. I would argue that Epicurus' idea ought to be read not simply as an ancient version of a familiar argument, but an indication of how rich and complex ancient thought on aesthetics actually was. My paper consists of three main parts: determining the scope of 'aesthetic disinterestedness', examining the Epicurean treatment of art as well as the classification of desire and, finally, discussing the issues.

\section{Aesthetic disinterestedness}

Stolnitz's noted definition of aesthetic disinterestedness states that 'a certain mode of attention is indispensable to and distinctive of the perception of beautiful things.' 3 Stolnitz argues that disinterestedness emerges from Shaftsbury's ethical discussions and soon evolves into a fully-fledged aesthetic concept. The fundamental concept of aesthetic disinterestedness is fairly straightforward. It posits two distinct ways of perceiving aesthetic objects: instrumental and terminal. The former 'mode of attention' is employed when, to use Alison's example, 4 a classic Greek statue is viewed as a historic object and its material, the context in which it was found and its dimensions are of primary interest. The latter, the terminal 'mode of attention', consists of concentrating and appreciating nothing but distinct aesthetic properties, such as 'majesty' and 'grace'.

As the concept developed, it became increasingly more nuanced. A significant milestone in its development was Alison's claim that an art critic looking at a piece of art or a philosopher contemplating in nature does not have

\footnotetext{
3 Stolnitz 1961:131.
}

4 Stolnitz 1961:138. 
a disinterested attitude. 5 According to Stolnitz, by the time of Alison... "the aesthetic" has become a self-conscious and articulate idea. Alison need not, consequently, consider it merely by opposition to non-aesthetic; he can examine the peculiarities of the aesthetic "state of mind" itself; and he can therefore bring out its less obvious features and make more subtle discriminations, e.g., between the aesthetic percipient and the critic, than his predecessors had discerned.'6 Here we find that aesthetic disinterestedness is neither a matter of simply looking at art (as opposed to any other object) nor even a matter of being interested in the aesthetic value of art. Instead, it is a matter of paying attention to nothing but the aesthetic properties of the given object.

The idea is simple yet powerful. It is also important to the discipline of aesthetics, because it raises the possibility that there is something distinct about the perception of aesthetic properties or, to be more precise, that the proper perception of aesthetic properties requires treating these properties as terminal, appreciable for the sake of themselves and for no other end whatsoever.

While trying to define aesthetics by means of the concept of aesthetic disinterestedness is a distinctly modern theoretical move, 7 the very idea that aesthetic value is terminal rather than instrumental is, I argue, not. I will show that a very similar concept is found in the extant evidence on Epicurus. My choice of philosophical schools is not motivated by the supposition that Epicurus was the first or the only one to theorise aesthetic value in this way. In fact, I would argue that there is evidence of very sophisticated discussions of these issues in antiquity. ${ }^{8}$ Yet the Epicurean thought on this matter offers an informative case study because it presents a careful and thorough analysis of

\footnotetext{
5 The reason being that art critics consider the artworks either in relation to the rules or in comparison to other artworks. A philosopher who goes to reflect and reason in nature also does not have a disinterested attitude, because such a person's attention is not concentrated not nature (see Stolnitz 1961:137).

${ }^{6}$ Stolnitz 1961:138.

7 Stolnitz's claim is more ambitious: 'The British were the first to envision the possibility of a philosophical discipline, embracing the study of all of the arts, one which would be, moreover, autonomous, because its subject matter is not explicable by any of the other disciplines (1961:131-132). It has, however, been criticised both explicitly (the most famous critique is Dickie 1964; although cf. Kemp 1999, for an argument that Dickie's analysis is not historicallysensitive enough to depict the views of disinterestedness theorists' views quite accurately) and implicitly (the very idea that aesthetics could be defined quite so easily is questioned by Walton 2007).

${ }^{8}$ To some extent, Stolnitz himself implies this when he notes that Shafsbury, the earliest of the thinkers in whose works the aesthetic disinterestedness appears, was interested in Plato/Plotinus and made the claim about to kalon (Stolnitz 1961:133).
} 
different kinds of pleasure as sources of value. The Epicureans show very well that the ancient discussions of topics pertinent to aesthetics are neither cursory nor undeveloped.

\section{Epicurus on the wrong approach to the arts}

The claim that Epicurus had made a distinct contribution to aesthetics might be a little surprising, because a number of sources report his critical views of certain approaches to art. 9 Athenaeus, for instance, even compared Epicurus to Plato, who is notorious for his critique of the arts. ${ }^{10} \mathrm{~A}$ more elaborate record of Epicurus' views is preserved in Plutarch. In the treatise That Epicurus Actually Makes a Pleasant Life Impossible, for instance, Plutarch claims the following:

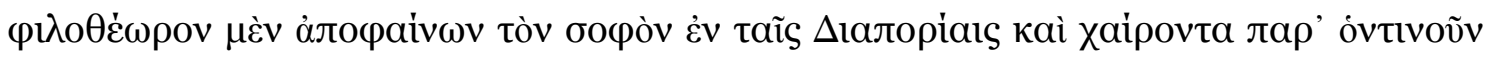

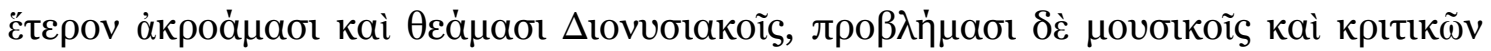

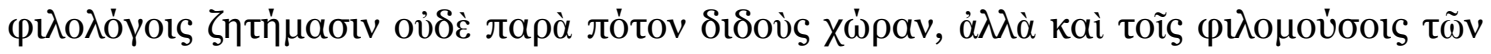

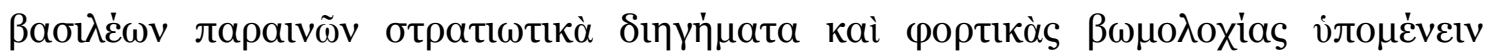

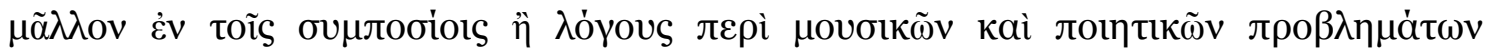

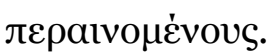

On the one hand, he [Epicurus] says in the Disputed Questions that the sage is a lover of spectacles and yields to none in the enjoyment of theatrical recitals and shows; but on the other he allows no place, even over wine, for questions about music and the enquires of critics and scholars and actually advises a cultivated monarch to put up with recitals of stratagems and with vulgar buffooneries at his drinking parties sooner than with the discussion of problems in music and poetry.11

These and similar claims make it clear why Athenaeus compared Epicurus to Plato, in whose Republic the mimetai are expelled from the ideal city. ${ }^{12}$ There is a further similarity between these two philosophers, however. It has been shown that Plato actually had a more nuanced attitude toward the arts

\footnotetext{
9 In the extant evidence, we find Epicurus views towards poetry, theatre performances and music to be fairly similar, so I am going to use the term 'art' to denote these phenomena.

10 Athenaeus Deipnosophistae $187 \mathrm{C}=\mathrm{U} 228$.

${ }^{11}$ Plutarch Moralia 1095C=U20, tr. Babbit.

12 Plato Republic 607a-d.
} 
than outright hostility. ${ }^{13}$ Elizabeth Asmis, moreover, has shown that Plutarch's record does not accurately reflect Epicurus' views. She argues the point as follows.

Plutarch attributes the following two views to Epicurus which are supposedly contradictory: (i) the wise man is a lover of sights and enjoys Dionysiac performances as much as anyone; (ii) no musical or philological discussions should take place while drinking, and kings should have military narratives and vulgar jesting rather than such discussions. ${ }^{14}$ In her astute and insightful analysis, Elizabeth Asmis shows, however, that there is no contradiction here. ${ }^{15}$ Claim (i) is directed at Plato's arguments about the arts in Republic. In this dialogue, the interlocutors contrast the lovers of sights and sounds, who run around Dionysiac festivals as if they let their ears for hire to every chorus, ${ }^{16}$ with philosophers, who are lovers of the sight of truth. ${ }^{17}$ Epicurus' claim that the wise man enjoys Dionysiac festivals, therefore, ought to be understood as a contention to Plato as follows:

The Epicurean wise person does not forsake the objects of sense perception in the pursuit of truth; for wisdom consists precisely in enjoying sensory experiences and having correct opinions about them. Epicurus agrees that the wise person loves the sight of truth, but insists that the love of truth encompasses the love of visual spectacles and auditory performances. In this confrontation with Plato, Epicurus gives clear approval to the enjoyment of musical and poetic performances..$^{18}$

The second claim by Epicurus regarding the avoidance of scholarly discussions of the arts, meanwhile, deals with a different issue entirely. Epicurus advises against listening to talks given by grammarians and similar experts. As Asmis suggests: 'Military talk, we may guess, might be useful for kings, even though a party is hardly the proper occasion for it, and buffoonery

\footnotetext{
${ }^{13}$ See, for instance, Moss 2007; Woodruff 2015:331-335.

14 In his own work Symposium, Epicurus discussed indigestion and fever (Athenaeus

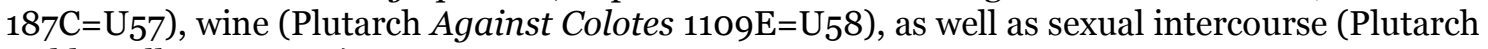
Table Talk 653B=U61).

15 Asmis 1995:19.

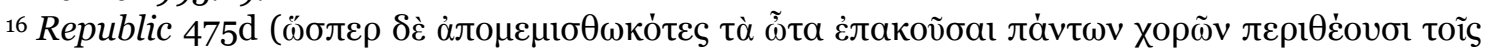
$\Delta$ iovvoioı), the speaker here is Glaucon.

${ }_{17}$ Republic 475e-476b.

${ }^{18}$ Asmis 1995:20.
} 
might be pleasant, whereas musicology and philology are neither.'19 Epicurus' point is not that the criterion for a good party activity is usefulness, but rather that one ought to be wary of the misdirection of attention from something truly pleasant (i.e., actual arts) to something that is not really pleasant (i.e., discussions about arts). 'Epicurus distinguished between two uses of poetry, education and entertainment, and condemned poetry wholesale as education, while welcoming it as entertainment.'20

The Epicurean claims about the wise man found in various doxographical sources also support this interpretation. Diogenes Laertius, for instance, records Epicurus' statements that only the wise person would discuss music and poetry in the correct manner (oj $\rho \tilde{\theta} \varsigma)^{21}$ and that such a person would be more delighted by festivals than anyone else. ${ }^{22}$ Sextus Empiricus, moreover, claims that Epicurus, in his book On Gifts and Gratitude, states that it would be necessary for the wise to learn literacy. ${ }^{23}$ These claims concern the most rational person, a wise man, and thus they show what behaviour would be perfectly rational according to the Epicurean standards. It follows, then, that discussing the poetry and music, as well as enjoying the festivals, is permissible as long as one adopts the correct approach. The correct - the most rational - approach in this case is to treat these activities as sources of certain kind of pleasure rather than education.

What is the right approach to the arts?

It seems clear, then, that Epicurus was against commenting on art or producing scholarship on art rather than admiring and appreciating art. Yet here a new question arises, that is, how the wise man's approach to artworks differs from the way in which people such as grammarians and art critics approach them? Similarly, one could ask what is it that the wise man would say

\footnotetext{
19 Asmis 1995:20.

${ }^{20}$ Asmis 1995:21. Cf. Blank 2009:217, 222. For Epicurus' rejection of paidea, see Sextus Empiricus Against the Professors 1.1=U227; Cicero On Ends 1.71-72=U227.

${ }^{21}$ Diogenes Laertius 10.120 $=\mathrm{U}_{569}$. The wise man would not, however, write poems (Diogenes Laertius $\left.10.120=\mathrm{U}_{5} 68\right)$.

${ }_{22}$ Diogenes Laertius 10.120=U593.

${ }^{23}$ Sextus Empiricus $M$ 1.49=U22. The Epicureans were notorious, however, for claiming that one does not need paidea in order to study philosophy; see, for instance, Cicero Fin. 2.12. These claims are not necessarily contradictory, because one of them concerns the pre-requisites to philosophy, while the other concerns the scope of the wise man's activities.
} 
about the arts if he is the only kind of person who is capable of discussing them correctly? David Blank has addressed this question and argued that '...the poetic passages which are truly useful for life, especially their gnomai, are clear and in no need of exegesis, while their unclear parts, e.g., foreign stories and allegories, are useless; a gnome is merely an assertion, but our intelligence demands proof, which is the province not of grammar, but of philosophy.'24

Is seems likely that the answer to the question of how the wise man would approach the arts would be somehow related to the wise man's philosophical (and Epicurean) knowledge, yet it is not clear what that would mean in terms of an attitude. Also, if the arts are not condemned, is there, in fact, anything positive that an Epicurean can derive from them?

The best way to answer these questions is by consulting the Epicurean views on desire and pleasure, ${ }^{25}$ that is, hedonistic ethics. This is because, for the Epicureans, the motivating factor for how one ought or ought not to act is their ethical doctrine about what actions bring the greatest amount of pleasure. In Cicero's On Ends, the Epicurean spokesperson Torquatus criticises those who call Epicurus uneducated and explains that Epicurus did not pursue such studies as music and geometry because they cannot contribute to making our lives more pleasant and, thus, better. Instead, he concentrated on the master art of living, which is more difficult and yet more rewarding. ${ }^{26}$ These claims echo the attitude found in a number of other testimonials that show pleasure to be the foundational concept in the Epicurean theoretical framework. In fact, Athenaeus preserves Epicurus' claim that the good cannot even be understood if one does not take into account sensory pleasures, including the ones caused by pleasant sounds and shapes. ${ }^{27}$

In order to answer the questions of how Epicurus envisaged engagement with the arts, we need to look into Epicurean ethics and ask: what

\footnotetext{
24 Blank 2009:223ff. This interpretation is based on Sextus Empiricus $M$ 1.270-6.

${ }^{25}$ Some accounts of aesthetic disinterestedness include pleasure and some do not. Kant, for instance, maintained that it is pleasure that is disinterested (The Critique of Judgement, book 1, First Moment, 1-3), while Shaftsbury separated sensory pleasure from disinterestedness (Shaftsbury's views are fairly complicated on this topic, however, see Stolnitz 1961:140). For a survey of the roles that pleasure plays in ancient aesthetics in general, see Destrée 2015.

${ }^{26}$ Cicero Fin. 1.71-72=U227.

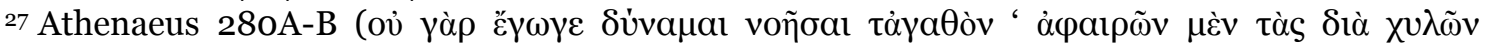

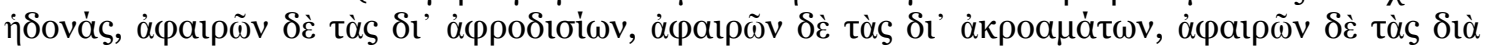

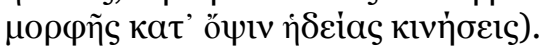


is the relationship between art and pleasure? or where do the arts fit in the overall hedonistic framework?

\section{Art and the classification of desires}

There is more than one way to be a hedonist. The fundamental feature of Epicurean hedonism, as opposed, for instance, to Cyrenaic hedonism, is prioritizing some pleasures over others. ${ }^{28}$ In the Letter to Menoeceus, while discussing the appropriate attitude to death, Epicurus states that the wise man would judge neither life nor death to be bad and supports this by the following statement:

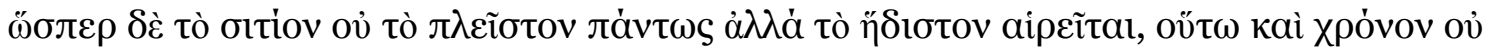

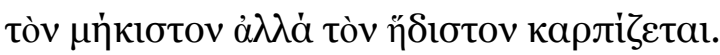

But just as he [the wise man] chooses the pleasantest food, not simply the greatest quantity, so too he enjoys the pleasantest time, not the longest. ${ }^{29}$

Later in the same work he also states that 'every pleasure, then, because of its natural affinity, is something good, yet not every pleasure is choiceworthy.' ${ }^{\prime}{ }^{\circ}$ The classification of desires ( $\left.\dot{\pi} \imath \theta v \mu i \alpha\right)$ and the principles that motivate the Epicurean choices of certain pleasures over others, therefore, are crucial for understanding how the Epicureans theorise values. Figuring out how aesthetic pleasures are classified in terms of desires is necessary for understanding what value the Epicureans allocated to them. Arguably the best source for Epicurus' classification of desires is the Letter to Menoeceus. In this work, the desires are classified into empty, natural and necessary as follows:

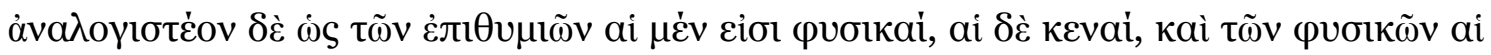

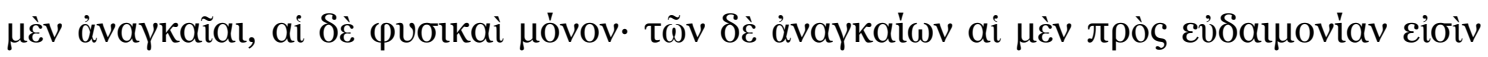

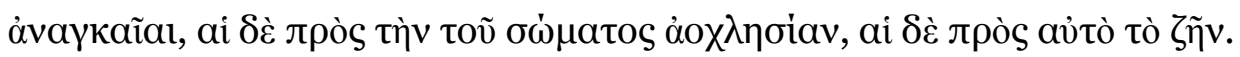

28 Diogenes Laertius (10.136-7=LS 21R) reports that the difference lies in the Epicurean recognition of static, as well as kinetic, pleasures. This division is well-known, although see Nikolsky 2001 for an argument that attributing this classification to Epicurus might be problematic. For a more in-depth discussion of the Cyrenaic and the Epicurean conceptions of pleasure, cf. Wolfsdorf 2013:147ff.

${ }^{29}$ Epicurus Letter to Menoeceus 126=LS 24 A, tr. Long and Sedley.

${ }^{30}$ Epicurus Men. 129=LS 21B, tr. Long and Sedley. 
We must reckon that some desires are natural and others empty, and of the natural some are necessary, others natural only; and of the necessary some are necessary for happiness, others for the body's freedom from stress, and others for life itself. ${ }^{31}$

Where in this classification can we place aesthetic experience? Quite fortunately, there is a fairly large number of testimonia regarding Epicurus' views on various desires, pleasures and their values. In the remaining part of this section, I am going to examine these sources in order to find examples for each class of desire.

The first division is into natural and empty desires. Here, we must ask which division could the arts belong to, according to Epicurus? Are the arts natural or empty? It seems reasonable to assume the latter. After all, the arts are not necessary for human constitution and well-being; there is no record of anyone dying from a lack of poetry in their life. In fact, one fragment states precisely this, namely, that one can live one's life perfectly well without ever coming in contact with the arts. ${ }^{2}$ The characterisation of empty desires, however, is quite specific and, I argue, does not agree with the way in which aesthetic value is described by the Epicurean corpus.

Epicurus' Key Doctrines contains the same classification of desires as in the Letter to Menoeceus, with one notable addition, namely, the claim that false desires arise through false expectations. 33 It is noteworthy that there is an established idiom in Greek in which 'empty' is used for what is futile or pointless, and so an empty belief is not a simple factual error but a mistake which renders your efforts pointless, side-tracking your life away from the path to happiness. Empty beliefs, then, are errors which are harmful and dysfunctional for the agent.'34

In Lucretius, we find the following passage which seemingly would support the interpretation of aesthetic experiences as empty desires:

...neque natura ipsa requirit,

si non aurea sunt iuvenum simulacra per aedes

\footnotetext{
${ }^{31}$ Epicurus Men. 127=LS 21B, tr. Long and Sedley.

32 See, for instance, Cicero Tusc. 5.116-117=U599.

33 Epicurus Key Doctrines 29.

34 Annas 1993:190.
} 
lampadas igniferas manibus retinentia dextris, lumina nocturnis epulis ut suppeditentur, nec domus argento fulget auroque renidet nec citharae reboant laqueata aurataque templa, cum tamen inter se prostrati in gramine molli propter aquae rivum sub ramis arboris altae non magnis opibus iucunde corpora curant, praesertim cum tempestas adridet et anni tempora conspergunt viridantis floribus herbas.

Nor does nature itself require it, if there are no golden statues of youths in the entrance halls grasping fiery torches in their right hands to provide evening banquets with light, or if the house does not gleam with silver and shine with gold and a carved and gilded ceiling does not resound to the lute, when, in spite of this, men lie together on the soft grass near a stream of water beneath the branches of a lofty tree refreshing their bodies with joy and at no great cost, especially when the weather smiles and the season of the year spreads flowers all over the green grass. 35

At first sight, the passage appears to include few distinctly aesthetic phenomena, yet it is noteworthy that all the objects mentioned are items of luxury. The passage, therefore, deals with the desire of opulence, wealth and social status rather than art. Consequently, the aesthetic objects, golden statues and music accompaniment, are here because they signify wealth and are examples of empty desires. ${ }^{36}$ Arguably, Lucretius' main point here is the same as that expressed by Epicurus in the Letter to Menoeceus when he says that what is natural is easy to get, whereas what is groundless is hard to attain. 37 So in this case, such objects as gold statues and music accompaniment are said not to contribute to pleasure properly because they are signs of wealth, rather than objects of aesthetic appreciation.

It is, therefore, luxury that ought to be treated as an empty desire, although Rafael Woolf has shown that Epicurus' attitude to luxury is more nuanced than it might appear at first sight. He argues that, in the sense that

\footnotetext{
35 Lucretius 2.20-34=LS 21W, tr. Long and Sedley.

${ }^{36} \mathrm{Cf}$. Sharples 1996:87.

37 Epicurus Men. 130.
} 
luxury is not necessary for either survival or happiness, it is an empty desire, yet 'Epicurus is comfortable with the idea of luxury as something that any reasonable person might choose if offered it. What he rejects, again, is both its puritanical disavowal and its strenuous pursuit. His classification of luxury as an object of empty desire reflects his attitude toward the latter conjunct; it does not entail the former.' 38

While empty desires are not actually beneficial, the pleasures derived from art must belong to a different category because some evidence suggests that they are, in some sense, beneficial. In book three of Tusculan Disputations, Cicero cites Epicurus as claiming that the very notion of 'the good' cannot be understood at all if sensory pleasures, including the ones received by means of listening to pleasant sounds and looking at pleasant sights, are taken away. 39 This clearly shows that pleasures derived from aesthetic phenomena are informative, so the desire for them are not based on false beliefs and, therefore, not empty.

Desires relating to art must be located somewhere in one of the subcategories of the natural desires, either as 'merely natural' or as 'necessary'. Since the necessary desires are further subdivided into three categories and are defined fairly precisely, I am going to start with them.

First of all, the arts are not likely to be put in the category of life itself, because this clearly applies only to desires that are necessary for being alive. It was already mentioned that Epicurus maintained that life is possible without access to artistic activities. It is the desire of eating that informs and defines all the other pleasures, according to the following short claim of Epicurus preserved by Athenaeus:

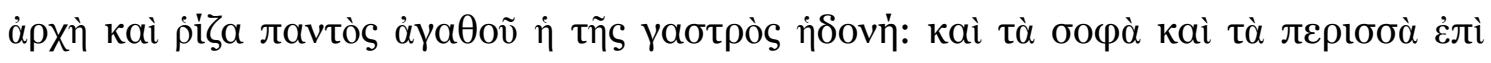

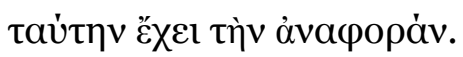

The pleasure of the stomach is the beginning and root of all good, and it is to this that wisdom and over-refinement actually refer..$^{\circ}$

\footnotetext{
${ }^{38}$ Woolf 2009:168.

39 Cicero Tusculan Disputations 3.41=U67=LS 21L. The whole passage is cited and discussed in greater detail below.

${ }_{40}$ Athenaeus 546F=U409=LS 21M, tr. Long and Sedley. Cf. Cicero Tusc. 3.42.
} 
The desires necessary for life, then, are the ones that are fundamental to human life, such as eating and drinking. The second half of the sentence is informative too for my purposes as it suggests that over-refinement ( $\tau \grave{\alpha}$

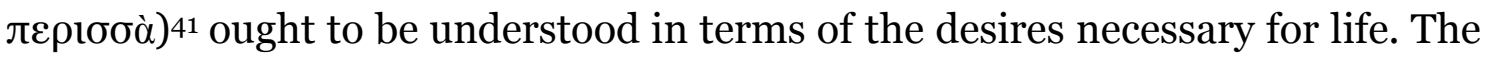
passage seems to suggest that the best way to approach over-refinement is by referring to what is hedonistic in them in a fundamental sensory way. At the same time, pleasures derived from interacting with the arts are certainly not in the category of desires necessary for life.

In fact, the other two categories of necessary pleasures are unlikely candidates for the classification of the arts as well, primarily because the arts are something that an Epicurean could live a happy life without. In his Tusculan Disputations, Cicero discusses Epicurus' claim that the wise man would always be happy, including the question of whether this would be the case if the wise man had lost the sense of sight or hearing. The Epicurean answer to this concern consists of the claim that mind, rather than senses, plays the most important role in securing a pleasant life. This claim is illustrated with several examples of people who were either blind or deaf yet lived admirable political and intellectual lives. In addition to this, a number of arguments illustrate how Roman Epicureans are 'deaf' when it comes to Greek, the language they do not understand; moreover, it is said that even though a deaf person does not hear singing, she or he also cannot hear unpleasant sounds, such as the grating of a saw. And if they happen to be fond of singing, they only need to remember the following:

...primum cogitare debent, ante quam hi sint inventi, multos beate vixisse sapientes, deinde multo maiorem percipi posse legendis his quam audiendis voluptatem.

...they ought to consider first that many wise men lived happily before music was discovered; besides, they may have more pleasure in reading verses than in hearing them. ${ }^{42}$

${ }^{41}$ Note that this word is often associated with very great knowledge (for example Aristotle Metaphysics 983a3) or overly zealous interest (Euripides Bacchae 425-430).

${ }^{42}$ Cicero Tusc. 5.116-117=U599, tr. Yonge, slightly altered. 
A similar claim can be found in Sextus Empiricus' Against the Musicians, where it is stated that just because Plato welcomed music, we ought not to assume that it does contribute to happiness, since other philosophers, such as Epicurus, denied this and claimed that music was not beneficial.43 This short claim clearly suggests that music would not be in the category of pleasures necessary for happiness.

Happiness is also closely tied to the freedom from bodily disturbance, another sub-category of the necessary desires. In the Letter to Menoeceus, Epicurus defines pleasure as the telos of life but only in the sense of being free from bodily pain and mental disturbance, rather than in the sense of having pleasant experiences by drinking and enjoying parties. 44 In fact, the lack of bodily pain is said to be 'the limit of the magnitude of pleasures,'45 and once this state is achieved, the pleasures of the body do not increase, but only become varied. ${ }^{46}$ It is also noteworthy that some sources suggest that mental pains and pleasures are greater than bodily ones 47 and thus it is possible, just like some evidence suggests of Epicurus himself, to be in physical pain yet still to be in an overall pleasant state. 48

There is only one category left, the 'merely natural pleasures', and I would argue that the pleasures derived from art were most likely conceptualised by the Epicureans as belonging to this category. So far, we found that aesthetic experience cannot be properly classified as either empty or necessary desire, and 'merely natural' is the only category left. This is not the only reason to place aesthetic experience in this category, however. There is some evidence that supports the view that the arts are merely natural pleasures. In Tusculan Disputations, Cicero presents a fairly substantial quote from Epicurus that states the following:

\footnotetext{
43 Sextus Empiricus $M$ 6.27=U229b. The same claim can be found in the extant evidence on Philodemus' views, see Blank 2009:221-222 for a thorough analysis of Philodemus views on the this topic.

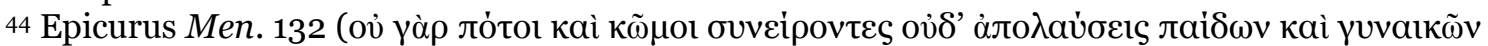

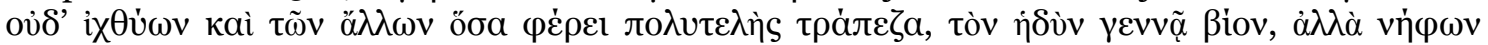

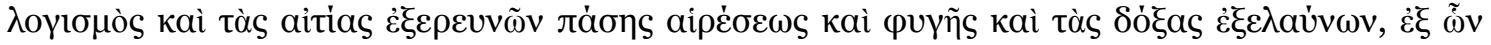

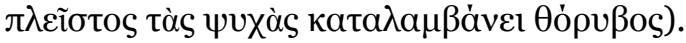

45 Epicurus KD 3=LS 21C tr. Long and Sedley, also see Plutarch Mor. 1089D=U 68=LS 21N.

${ }^{46}$ Epicurus $K D 18=\mathrm{LS} 21 \mathrm{E}$.

47 Diogenes of Oenoanda 38.1.8-3.14=LS 21V.

${ }^{48}$ Diogenes Laertius 10.22; Cicero Fin. 2.96-97.
} 
nec equidem habeo, quod intellegam bonum illud, detrahens eas voluptates quae sapore percipiuntur, detrahens eas quae rebus percipiuntur veneriis, detrahens eas quae auditu e cantibus, detrahens eas etiam quae ex formis percipiuntur oculis suavis motiones, sive quae aliae voluptates in toto homine gignuntur quolibet sensu. nec vero ita dici potest, mentis laetitiam solam esse in bonis. laetantem enim mentem ita novi: spe eorum omnium, quae supra dixi, fore ut natura is potiens dolore careat.

Indeed, I do not know what is meant by 'the good,' if you take away the pleasures that are experienced through taste, and the pleasures experienced in sex, and the sweet motions which are experienced by the ears through music and by the eyes through forms, and the other pleasures which are generated in the whole person by any of the senses. Nor is it possible to say that gladness of mind is the only thing that is good. For as I understand it, what it means for a mind to be glad is for it to have an expectation of possessing, naturally and without pain, all those things which I have named.49

In this passage, we find not only the Epicurean claim that sensory pleasures are fundamental to the notion of the good, but also an argument that motivates this claim. The argument suggests that positing 'gladness of mind' as the good is a misunderstanding, because all that this gladness amounts to is an expectation of experiencing pleasure.

For the purposes of this paper, the passage is especially illuminating because it presents pleasure derived from aesthetic experiences as informative of the good as, for instance, the pleasure of eating. There is an emphasis on sensory perception, which makes it clear that, for an Epicurean, the right way of approaching aesthetic objects is by concentrating on their aesthetic properties and the pleasure derived from perceiving them. The arts, then, belong to the category of merely natural desires. They are capable of causing sensory pleasures that constitute the good, so they are natural. They are not, however, in any way necessary for either life or happiness, and therefore, they have to be merely natural.

Both empty and merely natural - as opposed to necessary - are the kind of pleasures that one could do without, as far as a happy Epicurean life is concerned, yet there must be an important difference if they are placed in such different categories. Empty desires are formed on the basis of false beliefs, yet

49 Cicero Tusc. 3.41=U67=LS 21L (cf. Diogenes Laertius 10.6), tr. Graver. 
natural desires are not merely those that are based on true beliefs, as Julia Annas notes, but also those desires that are understood in terms of human nature. $5^{\circ}$ Annas argues that the substantial distinction between merely natural and empty desires is implied rather than spelled out clearly. This distinction is between generic and specific desires. The desire for expensive food would be a natural, albeit not a necessary one. ${ }^{11}$ If, however, a person 'turns out to care very much for lobster, making efforts to get it and sulking if it is not on the menu, then the desire becomes an empty one, for it now depends on the belief that getting lobster, as opposed to something else to satisfy one's hunger, is worth caring about.' 52 The important insight here is that a desire for some object can be either natural or empty, depending on the attitude the person adopts towards the desired object. If the desire is for a more generic aspect of that object, the reasoning process is as follows: food is nourishing; lobster is food; hence I desire lobster. If the desire is for a specific aspect of that object, however, the reasoning would be as follows: the lobster is a good thing, hence I desire lobster. Of course, in the latter case, there is an error in making a value judgement. Lobster is not the good, pleasure is.

Annas' analysis of the distinction between natural and empty desires could be used to explain the Epicurean treatment of art very neatly. The desire to hear pleasant sounds and to see pleasant sights is a natural one, as human nature is inclined towards the pleasure. A wise man would visit festivals and enjoy them more than anyone else because the wise man would adopt a perfectly adequate attitude towards this experience: as something valuable purely for the pleasure derived from the sensual perception of the arts.53 The wise man would not, however, turn pursuit of the arts into an empty desire, that is, into the pursuit of knowledge and understanding, as this is simply what the arts are not capable of doing.

Thus we end up with the conclusion that the proper attitude to art, the one exemplified by the attitude adopted by the wise man, is that of disinterestedness in the sense that the proper attitude to art is the enjoyment of

\footnotetext{
50 Annas 1993:190.

${ }^{51}$ Epicurus KD 29. Cf. Porphyry On Abstinence 1.51.6-52.1=U464=LS 21J.

${ }^{2}$ Annas 1993:192, also see 193. Cf. Brown 2009:186-7 for a similar idea that a desire might become necessary in virtue of certain circumstances.

53 It might be worth bearing in mind that festivals were communal events and an important part of the life of the polis; see, for instance, Pedley 2005:78.
} 
sensory experience, the formal properties of art, rather than any other goal or meaning.

\section{Epicurus on aesthetic disinterestedness?}

Is it possible, then, to say that the notion of aesthetic disinterestedness can be found in Epicurus' works? The answer is far from straightforward. There are some very striking similarities between Epicurus' description of the proper approach to arts and Stolnitz description of aesthetic disinterestedness, yet the differences of context and theoretical commitments also ought to be taken into account. I argue that, more than anything else, the Epicurean texts problematize and theorise aesthetic experience in a way that certainly challenges Stolnitz assertion that ancient views on aesthetic experience were under-developed.

The distinct feature of aesthetic disinterestedness as theorised by Stonlitz was a 'mode of attention' that concentrated on aesthetic objects in a terminal, rather than an instrumental manner. Epicurus' works and testimonia contain claims that advocate similar attitude in the sense that the proper mode of attention when engaging with arts is a natural and, we might add, terminal, desire, which means that artistic objects are appreciated for the pleasure derived from their aesthetic properties and nothing else.

One striking similarity between Epicurus' and modern theorists of aesthetic disinterestedness is the claim that art critics do not possess the proper attitude to arts. We have seen that Epicurus' apparent attack on the arts is, in fact, an attack on art 'critics', grammarians, etc. Interestingly, a very similar view can be found in Stolnitz's article. To be precise, Stolnitz suggests that the claim (first made by Alison) that an art critic does not have a proper aesthetic attitude is a fundamental condition for the aesthetic disinterestedness. 54 In both cases, we find the claim that aesthetic objects ought to be approached and appreciated for the pleasure derived purely from those objects' aesthetic properties. Epicurus and the modern theorists, however, frame the same concept, quite differently.

One could argue that there remains a fundamental difference between the Epicureans and modern thinkers, namely, that the latter use aesthetic

54 See Stolnitz 1961:137. 
indifference for analysing the perception of art specifically, whereas artistic objects are certainly not special objects of perception for Epicurus. The thing that could be said of the arts in virtue of them belonging to the merely natural category of desires, could be said of expensive food and nice shoes. 55

The Epicurean position is by no means the weaker one, however. Assuming that aesthetic disinterestedness is peculiar to art raises the question of why art alone ought to be singled out in this way. Why would apples, for instance, not be objects of a disinterested attitude? In fact, Stolnitz does allow that there is no need to restrict aesthetic disinterestedness to artistic objects; any object can be contemplated disinterestedly as long as the contemplation is 'terminal', that is, we appreciate the object for what it is..$^{6}$ The mere fact that the Epicureans classify the attitude to art with the attitude to nice shoes, therefore, does not make them less deficient theorists on aesthetic issues.

One could argue that the Epicureans are not properly interested in questions about aesthetic experience because their agenda primarily concerns ethical value and the question of how one ought to live one's life. It is, however, certainly possible to be a theorist of aesthetic disinterestedness in the modern sense and also maintain that the good in life is something else. The very notion of aesthetic disinterestedness is fairly narrow as it only concerns the perception of aesthetic objects, and there are numerous ways in which it can relate to other areas of value theory, such as ethics. The Epicurean way of approaching these issues is just one of many possible and, again, does not make them deficient theorists.

Finally, it is worth noting that, more generally, the notion of aesthetic disinterestedness is by no means clear-cut nor universally accepted. The fact that Stolnitz shows the disagreement among the group of philosophers he is investigating regarding how exactly disinterestedness is perceived 57 indicates that there has to be some room for disagreement and discussion about the scope and the nature of disinterestedness even among the advocates of this concept. The Epicurean perspective, however different, ought to be included when discussing historic views about aesthetic value.

55 Cf. Philodemus' claim that arts are in no way more valuable for our understanding of pleasure than, for instance, cookery or perfumery in On Music 91.3-92.5.

${ }^{56}$ Stolnitz 1960:24.

57 Stolnitz 1961:141. 


\section{Conclusion}

At the beginning of this paper, I rehearsed Stolnitz' twofold claim: that the notion of aesthetic disinterestedness is an innovation of the $18^{\text {th }}$ century and that this innovation is the origin of the discipline of aesthetics. Even if we accept that ancient thinkers, such as the Epicureans, used notions similar to that of aesthetic disinterestedness, we still have a significant difference, namely, that Epicurean theorisation of this topic did not produce a new discipline. $18^{\text {th }}$ century thinkers talked about 'aesthetics' in a way that Greeks did not and there is no Greek term equivalent to 'aesthetic disinterestedness' that ties distinct ideas into a uniform theory. Yet by broadening our conception of the scope of the aesthetic enquiry, we gain access to a greater variety of ideas. As I have argued in this paper, the very concept of aesthetic disinterestedness, the distinction between the terminal and the instrumental mode of attention, is present in the Epicurean texts. The Epicureans treat this concept in a distinctive way their ideas are in no way less developed or inchoate, and hence they are certainly deserving of further study for the sake of the insights they contain and the questions they raise. 


\section{Bibliography}

Annas, J. 1993. The Morality of Happiness. Oxford: OUP.

Asmis, E. 1995. 'Epicurean Poetics.' In D. Obbink (ed.) Philodemus and Poetry. Oxford: OUP, pp.15-34.

Babbit, R. C. 1957. Plutarch. 'Moralia.', vol.14. London: Heinemann.

Blank, D. 2009. 'Philosophia and techne: Epicureans on the art.' In J. Warren (ed.) The Cambridge Companion to Epicureanism. Cambridge: CUP, pp.216233.

Brown, E. 2009. 'Politics and Society.' In J. Warren (ed.) The Cambridge Companion to Epicureanism. Cambridge: CUP, pp.179-196.

Destrée, P. 2015. 'Pleasure.' In P. Destrée \& P. Murray (eds) A Companion to Ancient Aesthetics. Malden, MA: Wiley Blackwell, pp.472-485.

Dickie, G. 1964. 'The Myth of the Aesthetic Attitude.', American Philosophical Quarterly 1, pp.56-65.

Graver, M. 2002. Cicero on the Emotions: Tusculan Disputations 3 and 4. Chicago: University of Chicago Press.

Kemp, G. 1999. 'The Aesthetic Attitude.', British Journal of Aesthetics 39(4), pp.392-399.

Long, A. and D. Sedley. 1987. The Hellenistic Philosophers. Cambridge: CUP, 2 vols.

Moss, J. 2007. 'What is imitative poetry and why is it bad?' In G.R.F. Ferrari (ed.) The Cambridge Companion to Plato's Republic. Cambridge: CUP, pp.415444.

Nikolsky, B. 2001. "Epicurus on pleasure.", Phronesis 46, pp.440-465.

Pedley, J. 2005. Sanctuaries and the Sacred in the Ancient Greek World. New York: CUP.

Sharples, R. W. 1996. Stoics, Epicureans and Sceptics: An Introduction to Hellenistic Philosophy. London: Routledge.

Stolnitz, J.1961. 'On the origins of aesthetic disinterestedness.', The Journal of Aesthetics and Art Criticism 20(2), pp.131-143.

Stolnitz, J. 1960. Aesthetics and Philosophy of Art Criticism. Cambridge: Riverside Press.

Walton, K. 2007. 'Aesthetics - What? Why? And Wherefore?', Journal of Aesthetics and Art Criticism 65(2), pp.147-161.

Wolfsdorf, D. 2013. Pleasure in Ancient Greek Philosophy. Cambridge: Cambridge University Press.

Woolf, R. 2009. 'Pleasure and desire.' In: J. Warren (ed.) The Cambridge Companion to Epicureanism. Cambridge: CUP, pp.158-178.

Woodruff, P. 2015. 'Mimesis.' In P. Destrée \& P. Murray (eds) A Companion to Ancient Aesthetics. Malden, MA: Wiley Blackwell, pp.329-340.

Yonge, C.D. 1877. Cicero's 'Tusculan Disputations.' New York: Harper\& Brothers. 